\title{
Inclusion of CFRP-Epoxy Composite for End Anchorage in NSM-Epoxy Strengthened Beams
}

\author{
Md. Akter Hosen, Mohd Zamin Jumaat, and A. B. M. Saiful Islam \\ Department of Civil Engineering, Faculty of Engineering, University of Malaya, 50603 Kuala Lumpur, Malaysia \\ Correspondence should be addressed to Mohd Zamin Jumaat; zamin@um.edu.my \\ Received 5 February 2015; Accepted 2 April 2015 \\ Academic Editor: Rui Vilar
}

Copyright ( $) 2015 \mathrm{Md}$. Akter Hosen et al. This is an open access article distributed under the Creative Commons Attribution License, which permits unrestricted use, distribution, and reproduction in any medium, provided the original work is properly cited.

\begin{abstract}
Nowadays, the use of near surface mounted (NSM) technique strengthening reinforced concrete (RC) structural members is going very popular. The failure modes of NSM strengthened reinforced concrete (RC) beams have been shown to be largely due to premature failure such as concrete cover separation. In this study, CFRP U-wrap end anchorage with CFRP fabrics was used to eliminate the concrete cover separation failure. A total of eight RC rectangular beam specimens of $125 \mathrm{~mm}$ width, $250 \mathrm{~mm}$ depth, and $2300 \mathrm{~mm}$ length were tested. One specimen was kept unstrengthened as a reference; three specimens were strengthened with NSM steel bars and the remaining four specimens were strengthened with NSM steel bars together with the U-wrap end anchorage. The experimental results showed that wrapped strengthened beams had higher flexural strength and superior ductility performance. The results also show that these beams had less deflection, strain, crack width, and spacing.
\end{abstract}

\section{Introduction}

Strengthening of RC structures is essential for several reasons such as errors in construction, inadequate design, environmental effects, seismic retrofit, and functional change of structures and increases of structural capacity. CFRP composites have increase of use in structural strengthening around the world in the last decade. Because the CFRP has high strength to weight ratio, high stiffness, prominent durability in a change of environment, simplicity and rapidity of installation, flexibility in application, electromagnetically impartial, exceptional fatigue performance, and low thermal conductivity [1]. Different techniques are available for strengthening of RC members. Externally bonded reinforcement (EBR) [2-5] and near surface mounted (NSM) techniques are attractive for such strengthening [6-9]. Recently, NSM technique shows more attention over the EBR in the flexural strengthening of RC members [10, 11]. The NSM technique is good for severe environmental conditions and enhances bond performance and superior aesthetics [12]. However, the NSM method has some limitations. The width of the beam to be strengthened may not be wide enough to provide necessary edge clearance and clear spacing between adjacent NSM grooves [13]. Several experimental studies have examined the bond characteristics of NSM bars or strips in concrete using direct pull out tests $[14,15]$ or beam pull out tests [16]. The flexural behaviour of RC beams strengthened with NSM technique utilizing FRP bars was studied in [17]. The failure modes were explained as debonding probably occurring earlier between the CFRP bar and the epoxy interface.

The experimental studies of RC beams flexurally strengthened with NSM and externally bonded technique using AFRP bars and sheets, respectively, were performed [18]. The load capacity increased as the bond length increased and these two types of failure mode occurred, that is, debonding in the concrete epoxy interface and CFRP rod epoxy interface.

Experimental tests to examine the flexural behaviour of NSM CFRP bars and externally bonded reinforcement strengthened RC beams [19]. The NSM and EB reinforcement strengthened specimens failed by debonding. The cantilever RC beams were flexurally strengthened using NSM CFRP bars and increased the ultimate load up to $98 \%$ compared to the control beam and the peeling off failure occurred when some cracks reached to the end [20]. 
TABLE 1: Test matrix.

\begin{tabular}{lccc}
\hline Beam ID & Type & $\begin{array}{c}\text { NSM strengthening materials } \\
\text { Diameter }(\mathrm{mm})\end{array}$ & Number of bars \\
\hline CB & & Unstrengthened & End anchorage with CFRP fabrics \\
NS8 & 8 & & - \\
NS10 & 10 & 2 & 3 layers \\
NS12 & 12 & 3 layers \\
NS8U3 & Steel bars & 8 & 3 layers \\
NS10U3 & & 10 & 4 layers \\
NS12U3 & 12 & & \\
NS12U4 & & & \\
\hline
\end{tabular}

The internal reinforcement ratio, type and diameter of FRP bars (CFRP and GFRP), bonded length, and groove size were investigated on the RC beams strengthened with NSM technique [21]. It was found that application of NSM FRP bars was useful for improving the flexural strength of the RC beams. However, all strengthened beams failed by concrete cover splitting.

The effect of FRP (CFRP and GFRP), the number and area of NSM bars, and type of epoxy were also studied in [22]. All the strengthened beams failed by debonding. Among the double grooved strengthened beams, the CFRP supported beam displayed concrete cover separation whereas the GFRP exhibited concrete splitting.

The flexural strengthening of $\mathrm{RC}$ beams strengthened using EB CFRP sheets and plates with CFRP mechanical anchorage was studied [23]. It was found that the mechanical anchorage delays the debonding of strengthened beams. However, mechanical anchorage did not prevent the debonding.

However, from the existing literature, it is shown that $\mathrm{U}$-wrap end anchorage using CFRP fabrics to prevent the concrete cover separation of NSM strengthened RC beam specimens has been rarely incorporated. Therefore, in this paper the effectiveness of using U-wrap end anchorage with CFRP fabrics is proposed for eliminating concrete cover separation of flexurally strengthened NSM steel RC beam specimens being investigated. The loads, midspan deflection, and strain data were analysed to understand the failure loads, mode of failures, and cracking behavior.

\section{Experimental Programme}

A total of eight full size RC rectangular beams have been considered as test specimens. The beams were divided into three groups as shown in Table 1. The first group consisted of one beam as the control specimen (unstrengthened). The three specimens in the second group were strengthened by NSM steel bars and without end anchorage. Another four specimens in the third group were strengthened by NSM steel bars and end anchorage with CFRP fabrics.

2.1. Design of End Anchorage Length $\left(L_{a}\right)$. Flexural NSM steel strengthened RC beams may fail by concrete cover separation. To prevent the concrete cover separation, U-wrap

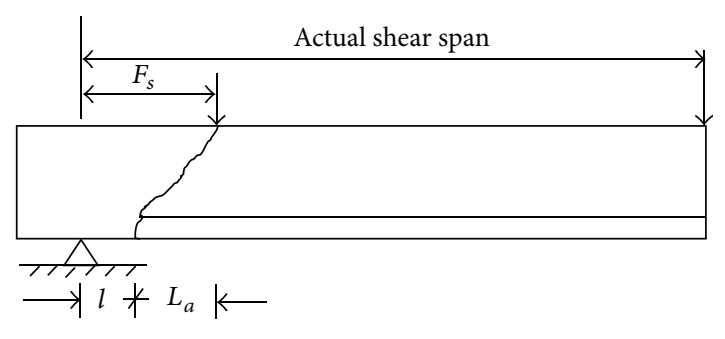

FIGURE 1: End anchorage design.

end anchorage using CFRP fabrics can be provided. The design of end anchorage was done [24] based on the fictitious shear span of the strengthened beams, where the concrete cover separation is likely to occur. The end anchorage should be provided at this factitious shear span for avoiding the concrete cover separation as shown in Figure 1.

The reinforced concrete beams are partially strengthened by NSM steel bars; it was shown that in the NSM curtailment end, shear force causes to occur crack in the unstrengthened portion of shear span. Therefore, the position of unstrengthened length $l$ is fixed and equals the location of critical shear crack [25].

The inclined shear crack may initiate at a point in the critical zone. Hence, the shear force is an inclined shear cracking load:

$$
V_{\mathrm{cr}, \mathrm{s}}=\frac{f_{r}^{\prime} b z_{0}}{m_{\mathrm{arch}} m_{\mathrm{bond}}}
$$

where

$$
\begin{aligned}
z_{0} & =(1-\sqrt{\rho}) d, \\
z_{c} & =\sqrt{\frac{l}{F_{s}}} z_{0}, \\
m_{\text {arch }} & =\frac{z_{0}}{z_{c}}=\sqrt{\frac{F_{s}}{l}}, \\
m_{\text {bond }} & =c_{1} .
\end{aligned}
$$

Substituting (2) in (1)

$$
V_{\mathrm{cr}, s}=\frac{f_{r}^{\prime} b(1-\sqrt{\rho}) d}{\sqrt{F_{s} / l} c_{1}} .
$$


And the shear force at flexural cracking load

$$
\begin{gathered}
V_{\mathrm{cr}, f}=\frac{M_{\mathrm{cr}}}{l}, \\
M_{\mathrm{cr}}=S f_{r}^{\prime},
\end{gathered}
$$

where

$$
\begin{aligned}
& f_{r}^{\prime}=c_{2} \sqrt{f_{c}^{\prime}}, \\
& S=\frac{I}{y}=\frac{n A_{s} d^{2}}{d / c_{4}}=\frac{n \rho b d^{3}}{d / c_{4}}=\frac{c_{3} \sqrt{\rho} b d^{3}}{d / c_{4}}=c_{3} c_{4} \sqrt{\rho} b d^{2} .
\end{aligned}
$$

Substituting (6) and (7) in (5)

$$
M_{\mathrm{cr}}=c_{2} c_{3} c_{4} \sqrt{\rho f_{c}^{\prime}} b d^{2}=k_{1} \sqrt{\rho f_{c}^{\prime}} b d^{2} .
$$

Substituting (8) in (4)

$$
V_{\mathrm{cr}, f}=\frac{k_{1} \sqrt{\rho f_{c}^{\prime}} b d^{2}}{l} .
$$

Substituting (6) in (3)

$$
V_{\mathrm{cr}, s}=\frac{c_{2} \sqrt{f_{c}^{\prime}}(1-\sqrt{\rho}) b d}{c_{1} \sqrt{F_{s} / l}}=k_{2} \sqrt{f_{c}^{\prime} \frac{l}{F_{s}}}(1-\sqrt{\rho}) b d .
$$

When the flexural and shear crack intersect (Figure 2), then equilibrating (9) and (10) the subsequent equation can be obtained:

$$
l=k_{3} \sqrt[3]{\frac{\rho\left(d / F_{s}\right)^{2}}{(1-\sqrt{\rho})^{2}}} F_{s},
$$

where $k_{3}=\left(k_{1} / k_{2}\right)^{2 / 3}$ is the constant, which is the ratio of fictitious shear span to the effective depth of the RC beam. By replacing constant $k_{3}$ in (1) with $F_{s} / d$, it can be rewritten into (11) as

$$
\text { Fictitious shear span, } F_{s}=\left[\left\{1-(\rho)^{1 / 2}\right\}^{2} \frac{l^{3} d}{\rho}\right]^{1 / 4} \text {, }
$$

where $f_{r}^{\prime}$ is the tensile strength of concrete, $b$ is the width of beam, $d$ is the effective depth of beam, $z_{0}$ is the actual internal moment lever arm length, $z_{c}$ is the internal moment arm length at critical point, $m_{\mathrm{arch}}$ and $m_{\mathrm{bond}}$ are the magnification factors (only have a meaning after flexural cracking), $\rho$ is the tension steel ratio $\left(A_{s} / b d\right), S$ is the section modulus, $f_{c}^{\prime}$ is the compressive strength of concrete, $n$ is the modular ratio $\left(E_{s} / E_{c}\right), E_{s}$ is modulus of elasticity of the main bar, $E_{c}$ is modulus of elasticity of the concrete, $c_{1}, c_{2}, c_{3}, c_{4}, k_{1}$, and $k_{2}$ are constant, $k_{1}=c_{2} c_{3} c_{4}, k_{2}=c_{2} / c_{1}$, and $M_{\mathrm{cr}}$ is the flexural cracking moment.

The end anchorage length can be found using (13) and it should be less than or equal to the effective depth of beam:

therefore, anchorage length, $L_{a}=\left[F_{s}-l\right] \leq d$.

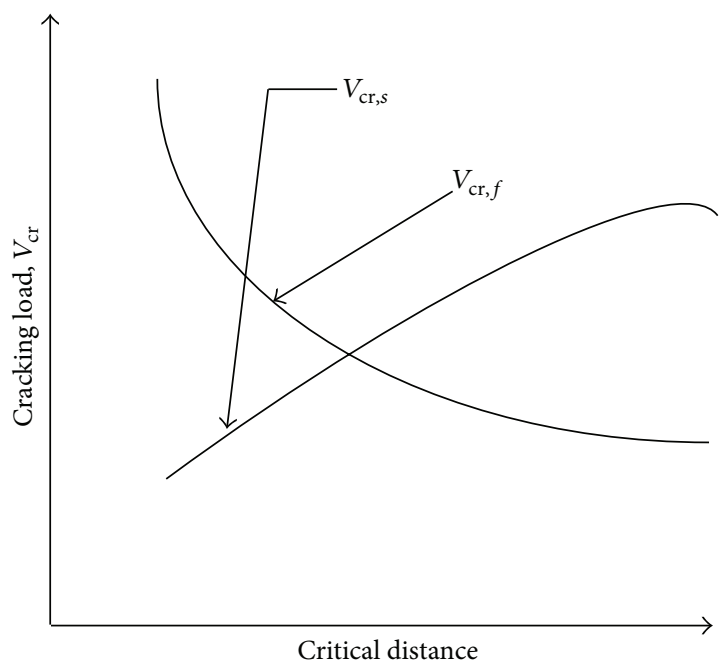

FIGURE 2: Schematical variation of cracking load along shear span.

TABle 2: Properties of reinforcing bars.

\begin{tabular}{lccc}
\hline $\begin{array}{l}\text { Diameter } \\
(\mathrm{mm})\end{array}$ & $\begin{array}{c}\text { Yield strength } \\
(\mathrm{MPa})\end{array}$ & $\begin{array}{c}\text { Ultimate } \\
\text { strength (MPa) }\end{array}$ & $\begin{array}{c}\text { Modulus of } \\
\text { elasticity (GPa) }\end{array}$ \\
\hline 6 & 520 & 570 & \\
8 & 379 & 536 & 200 \\
10 & 520 & 572 & \\
12 & 550 & 640 & \\
\hline
\end{tabular}

2.2. Materials. All beam specimens were cast using ordinary Portland cement. Crushed granite of maximum size $20 \mathrm{~mm}$ was used as coarse aggregate. Local mining sand was considered as fine aggregate. Fresh tap water hydrated the concrete mix during the casting and curing of the beams, cubes, prisms, and cylinders. The mix design of concrete had been carried out according to DOE method [26]. The 28-day average compressive strength, flexural strength, and modulus of elasticity of the concrete were $40 \mathrm{MPa}, 4.5 \mathrm{MPa}$, and $29875 \mathrm{MPa}$, respectively, based on tests of concrete three $100 \mathrm{~mm} \times 100 \mathrm{~mm} \times 100 \mathrm{~mm}$ cubes, $100 \mathrm{~mm} \times 100 \mathrm{~mm}$ $\times 500 \mathrm{~mm}$ prisms, and $150 \mathrm{~mm} \times 300 \mathrm{~mm}$ cylinders. The properties of reinforcing steel bars are presented in Table 2 . The CFRP fabrics thickness, ultimate strength, and modulus of elasticity were $0.17 \mathrm{~mm}, 4900 \mathrm{MPa}$, and $230 \mathrm{GPa}$, respectively. Sikadur 30, an epoxy adhesive, was used to bond the strengthening bars to the concrete substrate. The density was $1.65 \mathrm{~kg} /$ liter at $23^{\circ} \mathrm{C}$ after mixing. The bond strength with steel and concrete is $21 \mathrm{MPa}$ and $4 \mathrm{MPa}$, respectively. The compressive, tensile, and shear strength and modulus of elasticity according to the manufacturer of this adhesive are shown in Table 3. Furthermore, Sikadur 330 was used to bond the CFRP fabrics to the concrete substrate. The properties of Sikadur 330 were also shown in Table 3.

2.3. Procedure and Beam Specimens Preparation. The dimensions and reinforcement details of the prototype specimens 
TAble 3: Properties of Sikadur 30 and 330.

\begin{tabular}{lcc}
\hline \multirow{2}{*}{ Properties } & \multicolumn{2}{c}{ Strength $(\mathrm{MPa})$} \\
& Sikadur 30 & Sikadur 330 \\
\hline Compressive strength & 95 & - \\
Tensile strength & 31 & 30 \\
Flexural strength & 46.8 & 3800 \\
Modulus of elasticity & 11200 & 4500 \\
\hline
\end{tabular}

are shown in Figure 3. The beams were designed as underreinforced ( $\rho=A_{s} / b d=0.0084$ ) beams to initiate failure in flexure, in accordance with the ACI code [27]. The crosssectional dimensions of the beams were $125 \mathrm{~mm} \times 250 \mathrm{~mm}$ and the length of the beams was $2300 \mathrm{~mm}$. The effective span and shear span length of the beams are $2000 \mathrm{~mm}$ and $650 \mathrm{~mm}$, respectively. Three types of steel bars, $12 \mathrm{~mm}$, $10 \mathrm{~mm}$, and $6 \mathrm{~mm}$ in diameter, were employed in constructing the beam specimens. The internal tension reinforcement of all beams consisted of two deformed steel bars, $12 \mathrm{~mm}$ in diameter, which were bent ninety degrees at both ends to fulfill the anchorage criteria. Furthermore, two deformed steel bars of $10 \mathrm{~mm}$ diameter were used as hanger bars in the shear span zone. The shear reinforcement consisted of plain steel bars, $6 \mathrm{~mm}$ in diameter, distributed along the length of the beams as shown in Figure 3.

\subsection{Beam Specimens Strengthening}

2.4.1. Application of NSM Steel Bars. In NSM steel technique, strengthening bars are placed into grooves cut into the concrete cover of the RC beams and bonded using an epoxy adhesive groove filler. The installation of the strengthening steel bars began with the cutting of grooves maintaining the dimensions $1.5 d_{b} \times 1.5 d_{b}$ (where $d_{b}$ is the diameter of the tension reinforcement) in the concrete cover of the beam specimens at the tension face in the longitudinal direction. The grooves were made using a special concrete saw with a diamond blade. A hammer and a hand chisel were used to remove any remaining concrete lugs and to roughen the lower surface of the groove. The grooves were cleaned with a wire brush and a high pressure air jet. The strengthening steel bars were cleaned with acetone before introducing them into the grooves, in order to remove any possible dirt. The details of the grooves are shown in Figure 3(b). The grooves were half filled with epoxy and then the steel bar was placed inside the groove and lightly pressed. This forced the epoxy to flow around the inserted steel bar. In addition, required epoxy was used to fill the groove and level the surface. The bonded length of the NSM steel bars was $1900 \mathrm{~mm}$. To ensure that the epoxy achieved full strength, the beam was kept for one week of curing time.

2.4.2. Application of End Anchorage. After curing period of applied NSM steel bars, the concrete surface was prepared based on epoxy adhesive (Sikadur 330) specifications at the end of NSM steel. The soffit and two sides of width $100 \mathrm{~mm}$ of the specimens were prepared for end anchoring. Then, the surface was cleaned using brush and air jet. Finally, acetone was used to remove the dust and any other materials, which affect the bonding. A thin layer of adhesive was applied on the concrete surface to make sure that the adhesive fully covers the concrete surface. Later on, CFRP fabrics layers were placed on the beam as like as $U$ (soffit and two sides) and covered with epoxy adhesive. To achieve full strength of the epoxy, the beam was kept for one week of curing time.

2.5. Instrumentation and Experimental Setup. The instrumentation of the beams is shown in Figure 4. To measure the deflection at beam midspan, one vertical linear variable differential transducer (LVDT) was used. A number of gauges were used for measuring strains. Two $5 \mathrm{~mm}$ strain gauges were attached to the middle of the internal tension bars. A $30 \mathrm{~mm}$ strain gauge was placed on the top surface of the beam at midspan. DEMEC gauges were attached along the depth of the beam at midspan.

All beams were tested in four-point bending using an Instron Universal Testing Machine at heavy structural lab. The experiments were carried out using two types of controlling techniques. The first was load control which was used up to the strain hardening. Commencing from the strain softening region, the displacement control loading was maintained until failure of the beams. All data were recorded at 10 -second intervals. The rate of the actuator was set to $5 \mathrm{kN} / \mathrm{min}$ during load control and $1.5 \mathrm{~mm} / \mathrm{min}$ during displacement control. A Dino-Lite digital microscope measured the crack widths on the beams during testing.

\section{Experimental Results}

3.1. Flexural Strength and Deflection Behaviour. The results of the tested beams are given in Table 4. The NSM steel bars significantly influenced the stiffness of the strengthened specimens. The first crack load showed a remarkable increase (up to 103\%) of NSM steel with end anchorage over the control specimen (Figure 5(a)). Moreover, the experimental studies showed that all the strengthened specimens without end-anchored NSM steel bars and those with end-anchored NSM steel bars had higher flexural strength compared to the control specimen (Figure 5(b)). The ultimate loads of the specimens with NSM steel bars and end anchorage were higher (up to 49\%) than the ultimate loads of the specimens with NSM steel bars and without end anchorage. This could be due to the presence of end anchorage, which eliminated the failure through separation of the concrete cover. The NSM steel bars without end-anchored strengthened specimens failed by separation of the concrete cover before the specimens could achieve their full strength. Moreover, the specimens strengthened with NSM steel bars and with end anchor had the full strength before failure, which enhanced the ultimate strength over those without end-anchored strengthened specimens.

The load-midspan deflection curves for the control, the specimens strengthened with NSM steel bars with anchorage, and NSM steel bars without anchorage are shown in Figure 6 . All the beam specimens revealed the linear elastic 


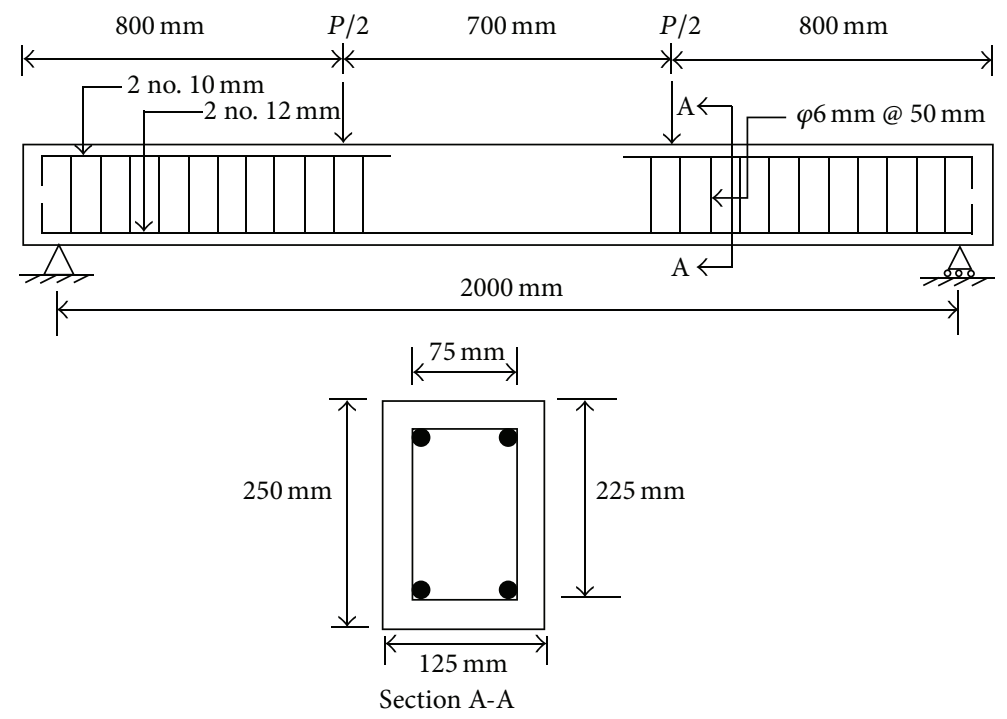

(a) Control beam
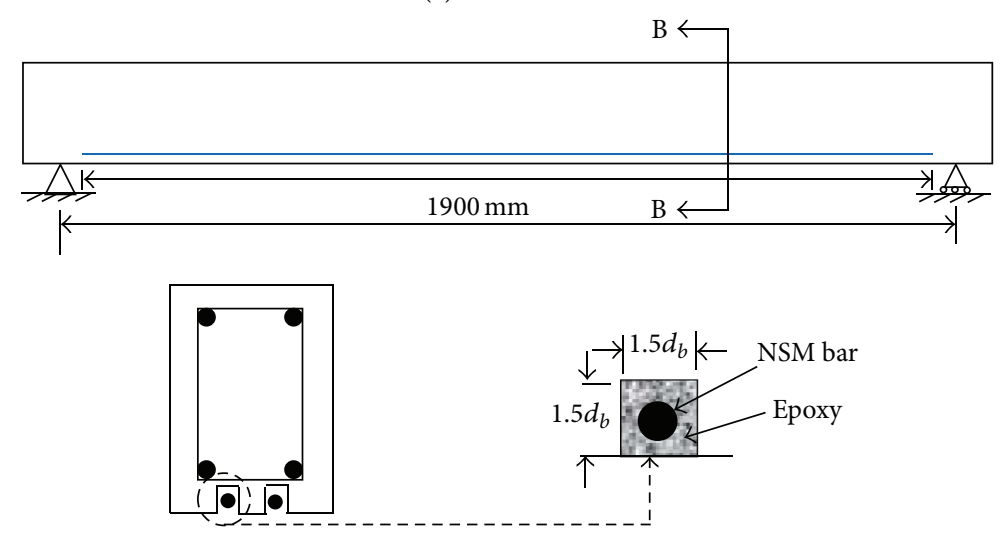

Section B-B

(b) NSM steel without end anchors

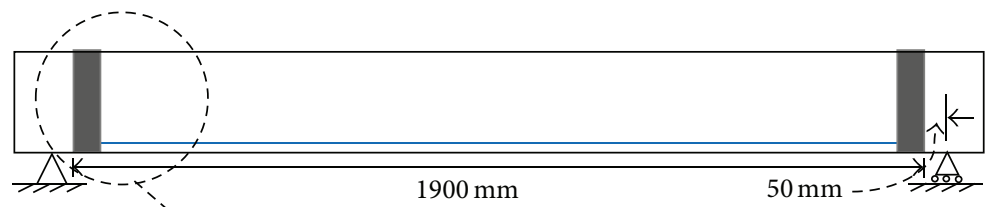

(c) NSM steel with end anchors

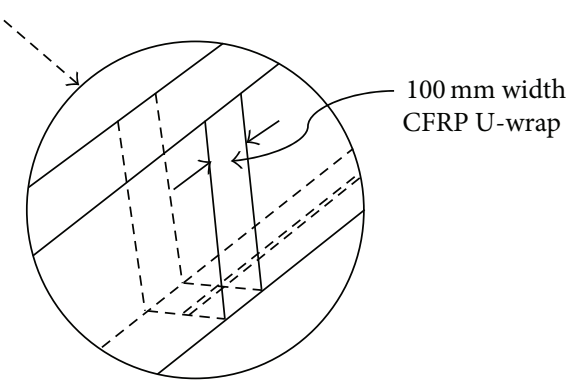

(d) Details of anchorage

Figure 3: Beam specimens details. 
TABLE 4: Summary of test results.

\begin{tabular}{lcccc}
\hline Beam ID & First crack load $(\mathrm{kN})$ & Ultimate load $(\mathrm{kN})$ & Deflection at failure $(\mathrm{mm})$ & Failure mode \\
\hline CB & 15.75 & 74.37 & 33.61 & 14.14 \\
NS8 & 20.00 & 106.24 & 30.71 & CCS \\
NS8U3 & 19.50 & 121.65 & 15.62 & FL \\
NS10 & 21.00 & 117.75 & 34.14 & CCS \\
NS10U3 & 27.00 & 153.78 & 11.95 & FL \\
NS12 & 26.60 & 136.75 & 30.64 & CCS \\
NS12U3 & 31.50 & 160.76 & 30.67 & FL \\
NS12U4 & 32.00 & 172.69 & & FL \\
\hline
\end{tabular}

FL: flexural failure, CCS: concrete cover separation.

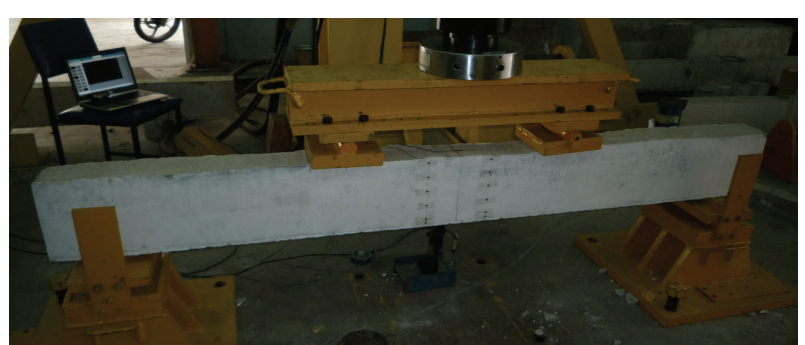

FIGURE 4: Experimental setup.

behaviour of deflection at the commencement followed by the first crack. Afterwards, the deflection curve developed nonlinearly as many flexural cracks were initiated. In the elastic region, the NSM steel bars and end-anchored strengthened specimens showed smaller deflections compared to the specimens strengthened with NSM steel bars but not end anchorage, except the NS12 specimen. However, at the failure stage, the specimens strengthened with NSM steel bars and end anchorage showed more deflection compared to the specimens strengthened with NSM steel bars but not end anchorage. The reason is that the specimens strengthened with NSM steel bars and end anchorage prevented concrete failure through separation of the cover and enhanced the ultimate loads.

3.2. Crack Characteristics. The load-crack widths of beams for CB, NS8, NS8U3, NS10, NS10U3, NS12, NS12U3, and NS12U4 are shown in Figure 7. The experimental first cracking loads of all specimens are revealed in Table 4. The first cracking loads of all end anchorage strengthened beams were higher than those without end anchorage except the NS8U3 specimen. It was noted that the strengthened beams with end anchorage had higher stiffness compared to those without end anchorage. The total number of cracks for CB, NS8, NS8U3, NS10, NS10U3, NS12, NS12U3, and NS12U4 were $11,15,16,17,18,20,22$, and 23 , respectively. The average crack spacing of those beams was $180 \mathrm{~mm}, 125 \mathrm{~mm}, 123 \mathrm{~mm}$, $115 \mathrm{~mm}, 105 \mathrm{~mm}, 95 \mathrm{~mm}, 90 \mathrm{~mm}$, and $85 \mathrm{~mm}$, respectively. The strengthened beams with end anchorage had a greater number of cracks and less crack spacing than those without end anchorage.

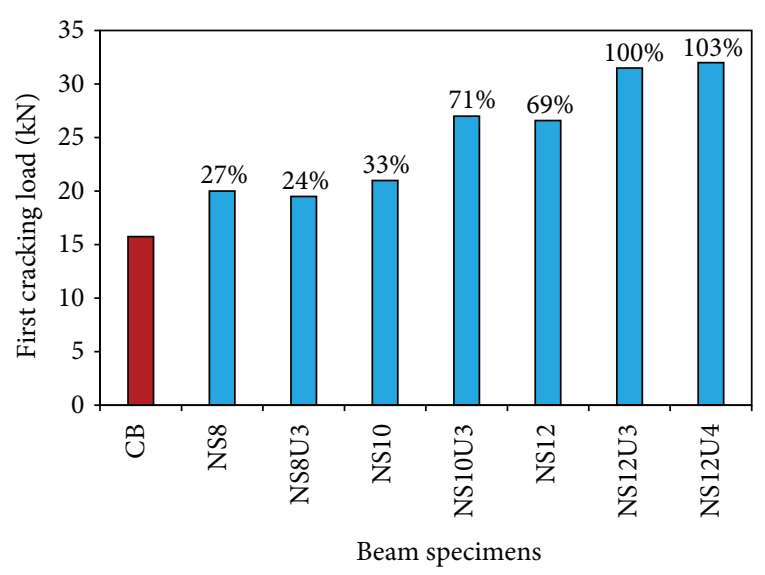

(a) First cracking load

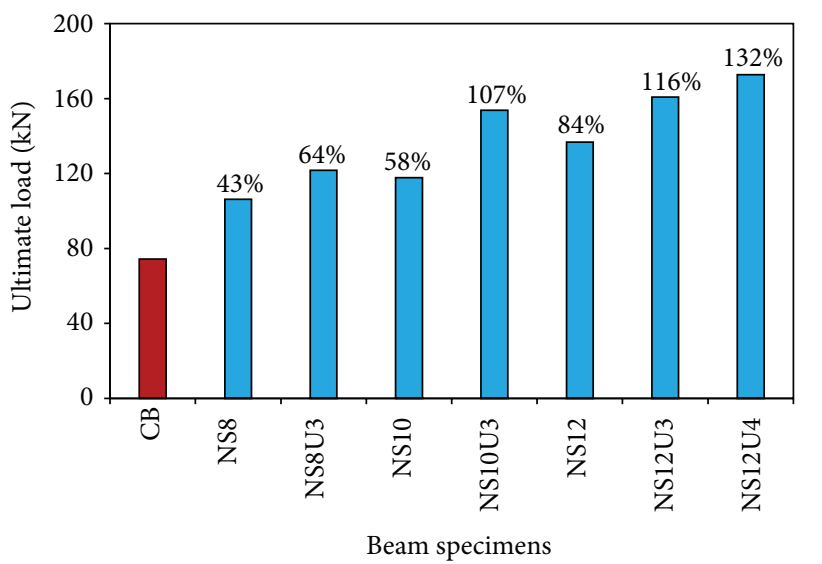

(b) Ultimate load

FIGURE 5: Load increment using NSM steel with and without end anchorage.

3.3. Mode of Failure. The failure modes of NSM steel bars strengthened specimens without and with end anchorage are revealed in Figure 8. The results show that the strengthened specimens without end anchorage failed by separation of the concrete cover in a brittle manner. However, the strengthened specimens with NSM steel bars and with end anchorage failed in flexure in a ductile failure mode. Hence, the failure through separation of the concrete cover of all the strengthened 


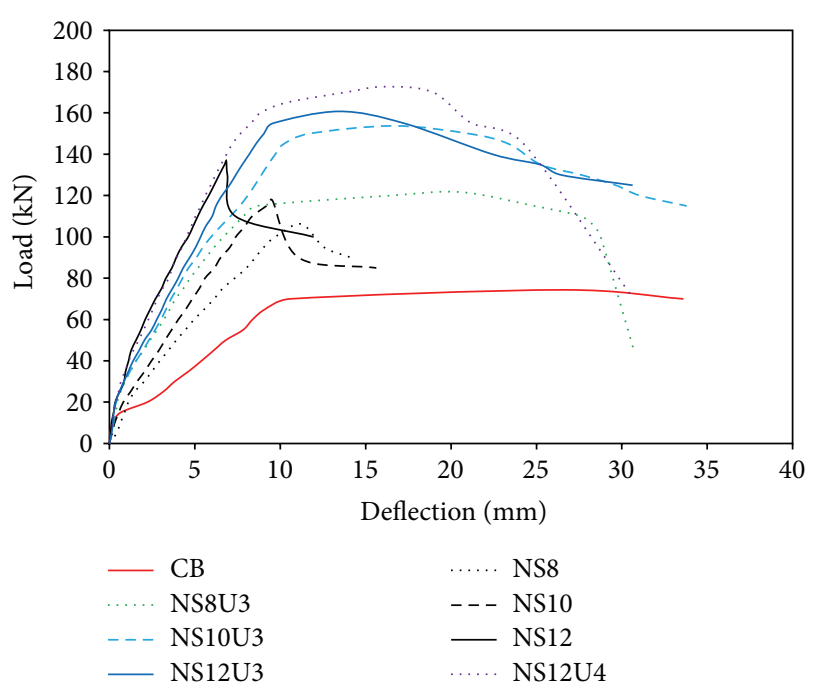

FIGURE 6: Load-midspan deflection.

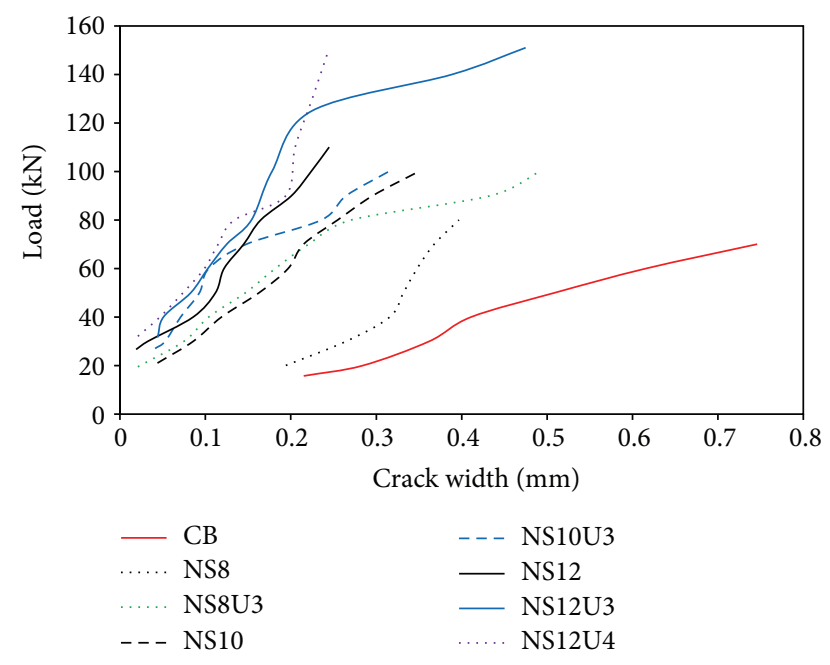

Figure 7: Load-crack width.

specimens without end anchoring is due to the formation of shear cracks at the curtailment edge of the NSM steel bars. Since the U-wrap end anchorage was firmly attached at the end of the NSM steel bars, it reduced the risk of the formation of shear cracks at the end of the NSM bars curtailment. Therefore, concrete cover separation did not occur and the failure mode shows ductile characteristics.

3.4. Damage Behaviour. The reduction in deflection due to strengthening with NSM steel bars and U-wrap end anchorage with CFRP fabric and strengthening with NSM steel bars and without end anchorage at $30 \mathrm{kN}, 50 \mathrm{kN}$, and $70 \mathrm{kN}$ service loadings is presented in Figure 9. The deflection of the strengthened specimens was reduced by a maximum of about $47 \%, 76 \%, 58 \%, 76 \%, 78 \%, 78 \%$, and $83 \%$ for NS8, NS8U3, NS10, NS10U3, NS12, NS12U3, and NS12U4, respectively, compared to the control specimen, due to the increased stiffness of the strengthened specimens. The compressive strain of the concrete at the top fibre of the specimens and reduction of the strain due to strengthening at $30 \mathrm{kN}$, $50 \mathrm{kN}$, and $70 \mathrm{kN}$ service loading are revealed in Figure 10. The compressive strain of the strengthened specimens was reduced by a maximum of about $51 \%, 49 \%, 53 \%, 70 \%, 61 \%$, $78 \%$, and $82 \%$ for NS8, NS8U3, NS10, NS10U3, NS12, NS12U3, and NS12U4, respectively, compared to the control specimen. The internal reinforcing tension steel bar tensile strain and reduction of the strain due to strengthening at $30 \mathrm{kN}$, $50 \mathrm{kN}$, and $70 \mathrm{kN}$ service loading are shown in Figure 11 . The reinforcing bar strain of the strengthened specimens was reduced by a maximum of about 38\%, 75\%, 59\%, 71\%, $75 \%, 74 \%$, and $80 \%$ for NS8, NS8U3, NS10, NS10U3, NS12, NS12U3, and NS12U4, respectively, compared to the control specimen. Therefore, the beam specimens strengthened with NSM steel bars with end anchorage showed more reduction in deflection and compressive and tensile strain compared to the specimens without end anchorage. This is because the failure mode of the strengthened beam specimens with end anchorage was due to flexure.

3.5. Tensile Strain of Main Rebars. The tensile strain of the main reinforcement was recorded at the midspan of the beams, as shown in Figure 12. The tensile strain of all strengthened specimens without and with end anchorages was smaller than the control specimen. The elastic zone of the strengthened specimens without end anchorage showed more tensile strain of the main reinforcement compared to those with end anchorage except NS12. However, the strengthened specimens with end anchorage showed more tensile strain in the main reinforcement compared to those without end anchorage at the failure stage. This is because the strengthened specimens without end anchorage failed by separation of the concrete cover in a brittle manner in contrast to the strengthened specimens with end anchorage, which failed in flexure in a ductile manner.

3.6. Ductility Analysis. Ductility is an important property, because it permits stress redistribution and allows precautions to be taken in the case of impending failure [28]. Figure 13 shows the details of the ductile behavior of the tested specimens. The deflection ductility index is expressed as a ratio between the deflections at failure load (midspan deflection at failure load) and the yield load (midspan deflection at yield load). The NSM steel with end anchorage strengthened specimens shows more ductility than that without end anchorage specimens due to flexural failure mode. Therefore, the end anchorage using CFRP fabrics improves the ductility of the NSM strengthened beam specimens.

3.7. Comparison of Results. Figure 14 shows the effectiveness of end anchorage on the flexurally strengthened NSM steel specimens. The specimens strengthened with NSM steel and end anchorage experienced higher ultimate loads and deflection than the beams strengthened with only NSM steel bars. Due to NSM steel with end anchorage strengthened specimens which used full strength of strengthening reinforcement by contrast only NSM steel strengthened specimens used few strengths. 


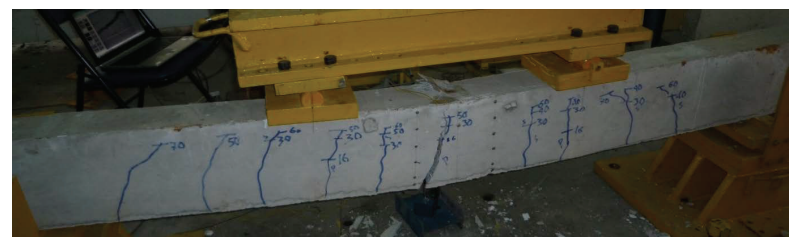

(a) $\mathrm{CB}$

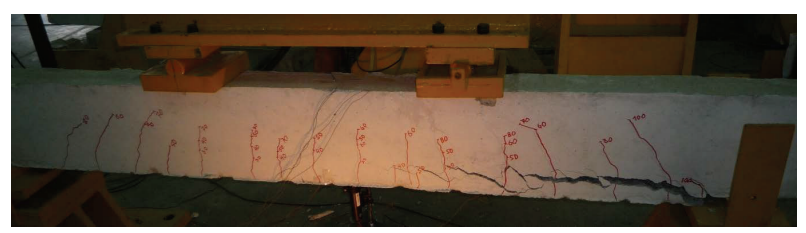

(c) NS10

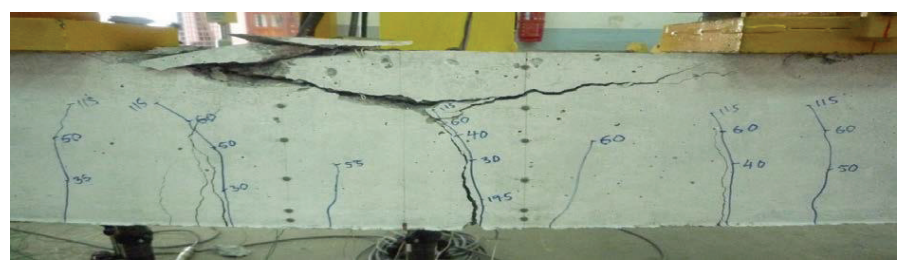

(e) NS8U3

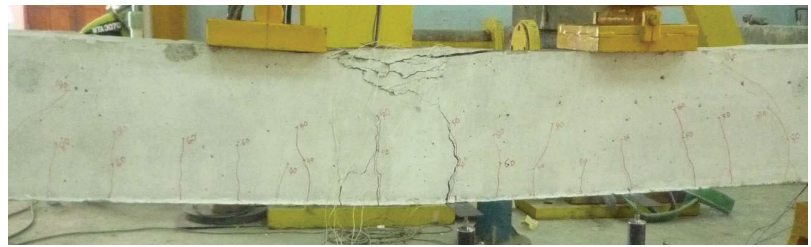

(g) NS12U3

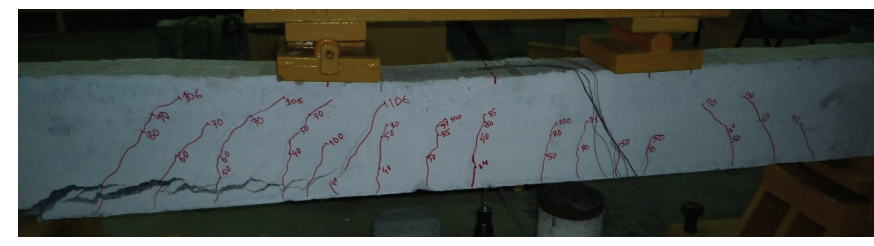

(b) NS8

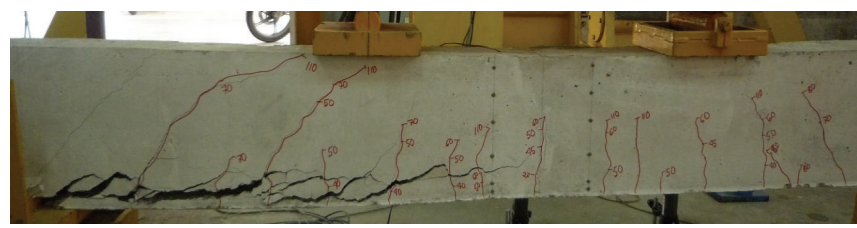

(d) NS12

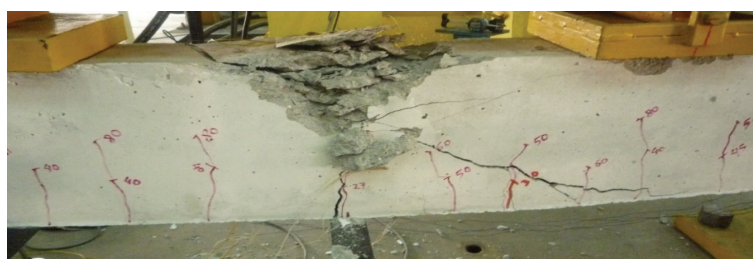

(f) NS10U3

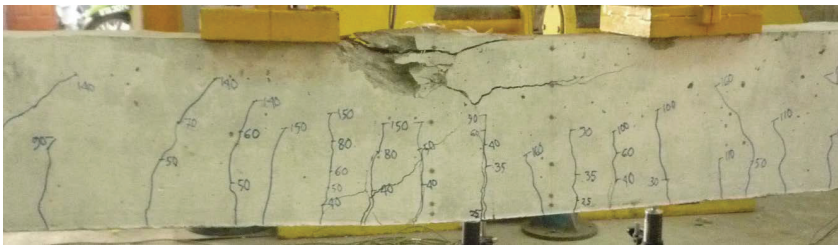

(h) NS12U4

FIGURE 8: Failure modes of beam specimens.

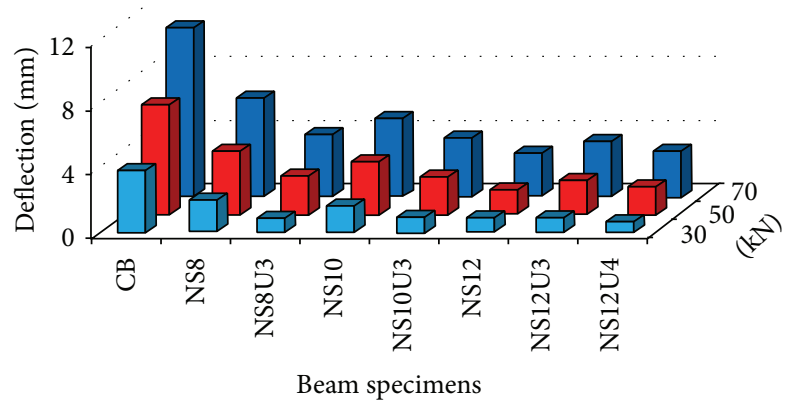
ㅁ $30 \mathrm{kN}$
- $50 \mathrm{kN}$
- $70 \mathrm{kN}$

FIGURE 9: Reduction in deflection with and without end-anchored strengthening.

\section{Conclusions}

The experimental investigation was conducted to study the effect of CFRP end anchorage on the flexural strength of RC beam specimens strengthened with NSM steel bars. The flexural capacity, deflection, mode of failure, concrete top fiber strain, tensile strain of main rebar, and crack widths of

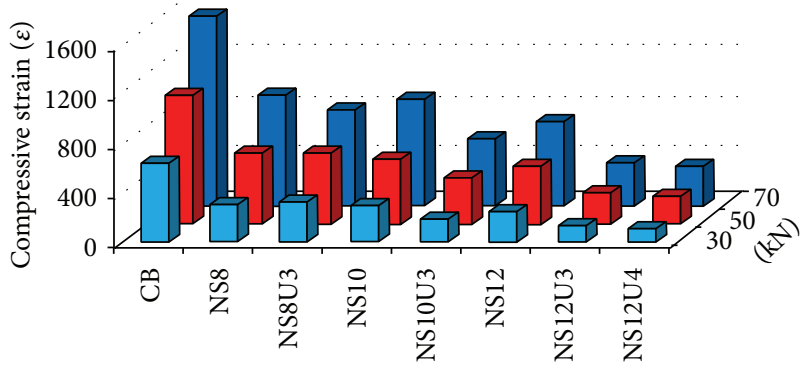

$30 \mathrm{kN}$
- $50 \mathrm{kN}$
$70 \mathrm{kN}$

Beam specimens

FIGURE 10: Reduction in concrete top fibre strain with and without end-anchored strengthening.

each of tested beams were analyzed. From the experimental results the subsequent conclusions can be drawn.

(i) The NSM steel without end anchorage increased the flexural strength up to $84 \%$. By contrast, NSM steel with end anchorage increased up to $132 \%$ (Figure $3(\mathrm{~b})$ ) compared to the control beam. 


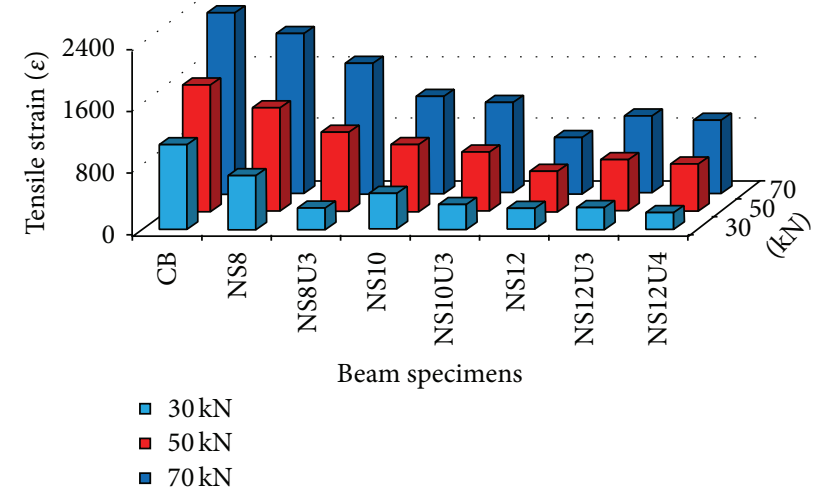

FIGURE 11: Reduction in strain main steel bar with and without endanchored strengthening.

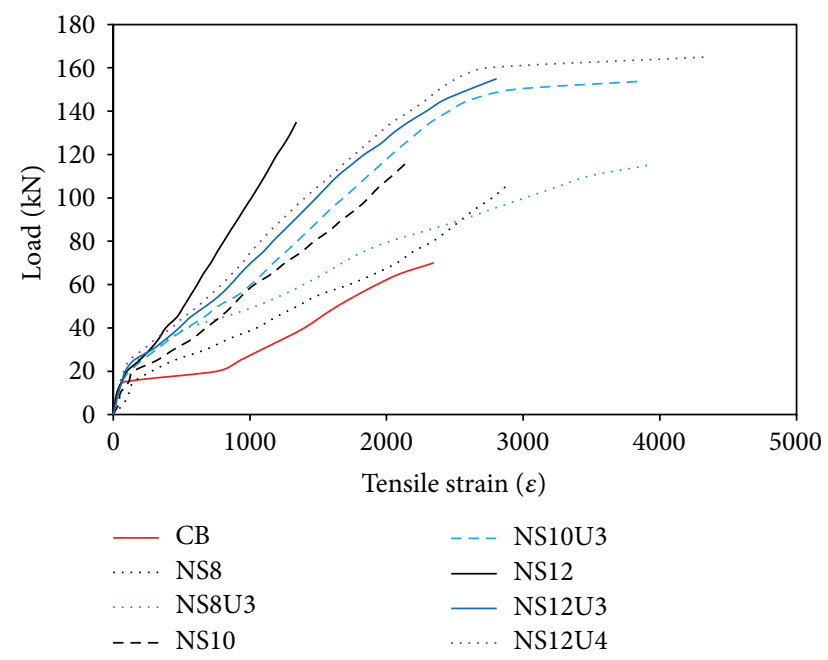

FIGURE 12: Load-tensile strain of main reinforcement.

Therefore, end anchorage significantly enhanced the flexural strength $(48 \%$ higher than that without end anchors).

(ii) The strengthened beams reduced the deflection (Figure 9), compressive strain of concrete (Figure 10), and tensile strain of internal reinforcement (Figure 11) compared to the control beam due to higher stiffness.

(iii) The NSM steel strengthened specimens without end anchorage showed concrete cover separation failure. However, the proposed U-wrap end anchorage using CFRP fabrics on the NSM steel strengthened specimens exhibited flexural failure. Therefore, end anchorage with CFRP fabrics eliminated the concrete cover separation failure.

(iv) The NSM steel with end anchorage increased first cracking loads and number of cracks and decreased the width of cracks more than strengthened specimens without end anchorage.

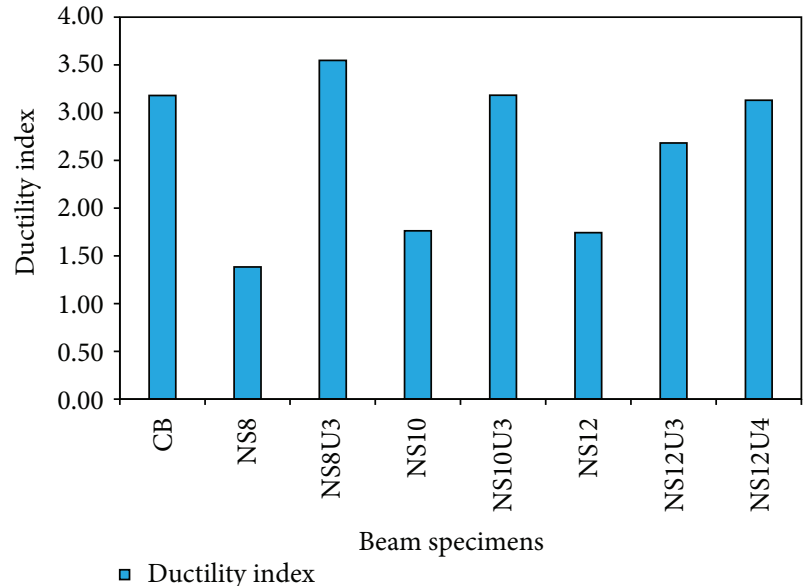

FIGURE 13: Ductility index of beam specimens.

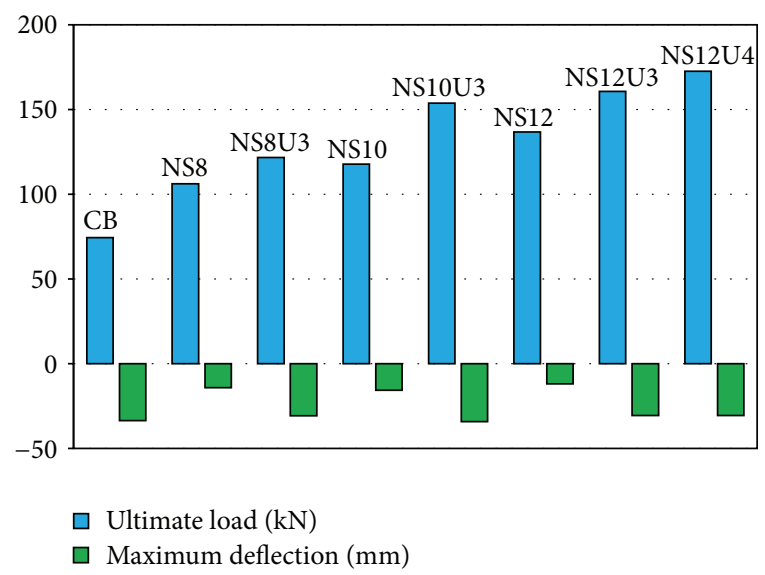

FIGURE 14: Comparison of ultimate load and the corresponding maximum deflection.

(v) At failure, NSM with end anchors exhibited larger deflection than NSM without end anchors. Hence, U-wrap end anchorage had an important effect on the deflection.

(vi) End anchorage enhances the ductility of NSM strengthened RC beams.

\section{Conflict of Interests}

The authors declare that there is no conflict of interests regarding the publication of this paper.

\section{Acknowledgment}

The authors gratefully acknowledge the financial support from the University of Malaya Research Grant RP018-2012A.

\section{References}

[1] L. J. Li, Y. C. Guo, F. Liu, and J. H. Bungey, "An experimental and numerical study of the effect of thickness and length of CFRP on performance of repaired reinforced concrete beams," 
Construction and Building Materials, vol. 20, no. 10, pp. 901-909, 2006.

[2] H. Saadatmanesh and M. R. Ehsani, "RC beams strengthened with GFRP plates. I. Experimental study," Journal of Structural Engineering, vol. 117, no. 11, pp. 3417-3433, 1991.

[3] P. A. Ritchie, D. A. Thomas, L.-W. Lu, and G. M. Connelly, "External reinforcement of concrete beams using fiber reinforced plastics," ACI Structural Journal, vol. 88, no. 4, pp. 490500, 1991.

[4] M. J. Chajes, T. A. Thomson Jr., T. F. Januszka, and W. W. Finch Jr., "Flexural strengthening of concrete beams using externally bonded composite materials," Construction and Building Materials, vol. 8, no. 3, pp. 191-201, 1994.

[5] A. Sharif, G. J. Al-Sulaimani, I. A. Basunbul, M. H. Baluch, and B. N. Ghaleb, "Strengthening of initially loaded reinforced concrete beams using FRP plates," ACI Structural Journal, vol. 91, no. 2, pp. 160-168, 1994.

[6] L. De Lorenzis, A. Rizzo, and A. La Tegola, "A modified pull-out test for bond of near-surface mounted FRP rods in concrete," Composites Part B: Engineering, vol. 33, no. 8, pp. 589-603, 2002.

[7] J. M. De Sena Cruz and J. A. O. De Barros, "Bond between nearsurface mounted carbon-fiber-reinforced polymer laminate strips and concrete," Journal of Composites for Construction, vol. 8, no. 6, pp. 519-527, 2004.

[8] A. Nanni, M. Di Ludovico, and R. Parretti, "Shear strengthening of a PC bridge girder with NSM CFRP rectangular bars," Advances in Structural Engineering, vol. 7, no. 4, pp. 297-309, 2004.

[9] D. Novidis, S. J. Pantazopoulou, and E. Tentolouris, "Experimental study of bond of NSM-FRP reinforcement," Construction and Building Materials, vol. 21, no. 8, pp. 1760-1770, 2007.

[10] M. Badawi and K. Soudki, "Flexural strengthening of RC beams with prestressed NSM CFRP rods-experimental and analytical investigation," Construction and Building Materials, vol. 23, no. 10, pp. 3292-3300, 2009.

[11] R. Capozucca and S. Bossoletti, "Static and free vibration analysis of RC beams with NSM CFRP rectangular rods," Composites B: Engineering, vol. 67, pp. 95-110, 2014.

[12] R. El-Hacha and M. Gaafar, "Flexural strengthening of reinforced concrete beams using prestressed, near-surfacemounted CFRP bars," PCI Journal, vol. 56, no. 4, pp. 134-151, 2011.

[13] L. De Lorenzis and J. G. Teng, "Near-surface mounted FRP reinforcement: an emerging technique for strengthening structures," Composites Part B: Engineering, vol. 38, no. 2, pp. 119-143, 2007.

[14] A. Bilotta, F. Ceroni, M. Di Ludovico, E. Nigro, M. Pecce, and G. Manfredi, "Bond efficiency of EBR and NSM FRP systems for strengthening concrete members," Journal of Composites for Construction, vol. 15, no. 5, pp. 757-772, 2011.

[15] I. A. Sharaky, L. Torres, M. Baena, and C. Miàs, "An experimental study of different factors affecting the bond of NSM FRP bars in concrete," Composite Structures, vol. 99, pp. 350-365, 2013.

[16] J. S. Cruz and J. Barros, "Modeling of bond between nearsurface mounted CFRP laminate strips and concrete," Computers \& Structures, vol. 82, no. 17-19, pp. 1513-1521, 2004.

[17] R. El-Hacha and S. H. Rizkalla, "Near-surface-mounted fiberreinforced polymer reinforcements for flexural strengthening of concrete structures," ACI Structural Journal, vol. 101, no. 5, pp. 717-726, 2004.
[18] N. Kishi, H. Mikami, Y. Kurihashi, and S. Sawada, "Flexural behaviour of RC beams reinforced with NSM AFRP rods," in Proceedings of the International Symposium on Bond Behaviour of FRP in Structures, pp. 337-342, Hong Kong, December 2005.

[19] W. T. Jung, Y. H. Park, J. S. Park, J. Y. Kang, and Y. J. You, "Experimental investigation on flexural behavior of RC beams strengthened by NSM CFRP reinforcements," in Proceedings of the 7th International Symposium on Fiber Reinforced Polymer Reinforcement for Reinforced Concrete Structures (FRPRCS7 '05), vol. 230, pp. 795-806, ACI, Kansas City, Mo, USA, November 2005.

[20] F. Al-Mahmoud, A. Castel, R. François, and C. Tourneur, "RC beams strengthened with NSM CFRP rods and modeling of peeling-off failure," Composite Structures, vol. 92, no. 8, pp. 1920-1930, 2010.

[21] S. M. Soliman, E. El-Salakawy, and B. Benmokrane, "Flexural behaviour of concrete beams strengthened with near surface mounted fibre reinforced polymer bars," Canadian Journal of Civil Engineering, vol. 37, no. 10, pp. 1371-1382, 2010.

[22] I. A. Sharaky, L. Torres, J. Comas, and C. Barris, "Flexural response of reinforced concrete (RC) beams strengthened with near surface mounted (NSM) fibre reinforced polymer (FRP) bars," Composite Structures, vol. 109, no. 1, pp. 8-22, 2014.

[23] A. Ali, J. Abdalla, R. Hawileh, and K. Galal, "CFRP mechanical anchorage for externally strengthened RC beams under flexure," Physics Procedia, vol. 55, pp. 10-16, 2014.

[24] W. Jansze, J. A. D. Uijl, and J. C. Walraven, "Flexural strengthening with externally bonded steel plates: design for beam shear and plate anchorage," in Challenges for Concrete in the Next Millennium, D. Stoelhorst and G. L. den Boer, Eds., vol. 2, A.A. Balkema, Amsterdam, The Netherlands, 1998.

[25] W. Kim and R. N. White, "Initiation of shear cracking in reinforced concrete beams with no web reinforcement," $A C I$ Structural Journal, vol. 88, no. 3, pp. 301-308, 1991.

[26] Department of the Environment, Design of Normal Concrete Mixes, Building Research Establishment, Watford, UK, 1988.

[27] ACI Committee, "Building code requirements for structural concrete and commentary," ACI 318-11, ACI Committee, 2011.

[28] G. Spadea, R. N. Swamy, and F. Bencardino, "Strength and ductility of RC beams repaired with bonded CFRP laminates," Journal of Bridge Engineering, vol. 6, no. 5, pp. 349-355, 2001. 

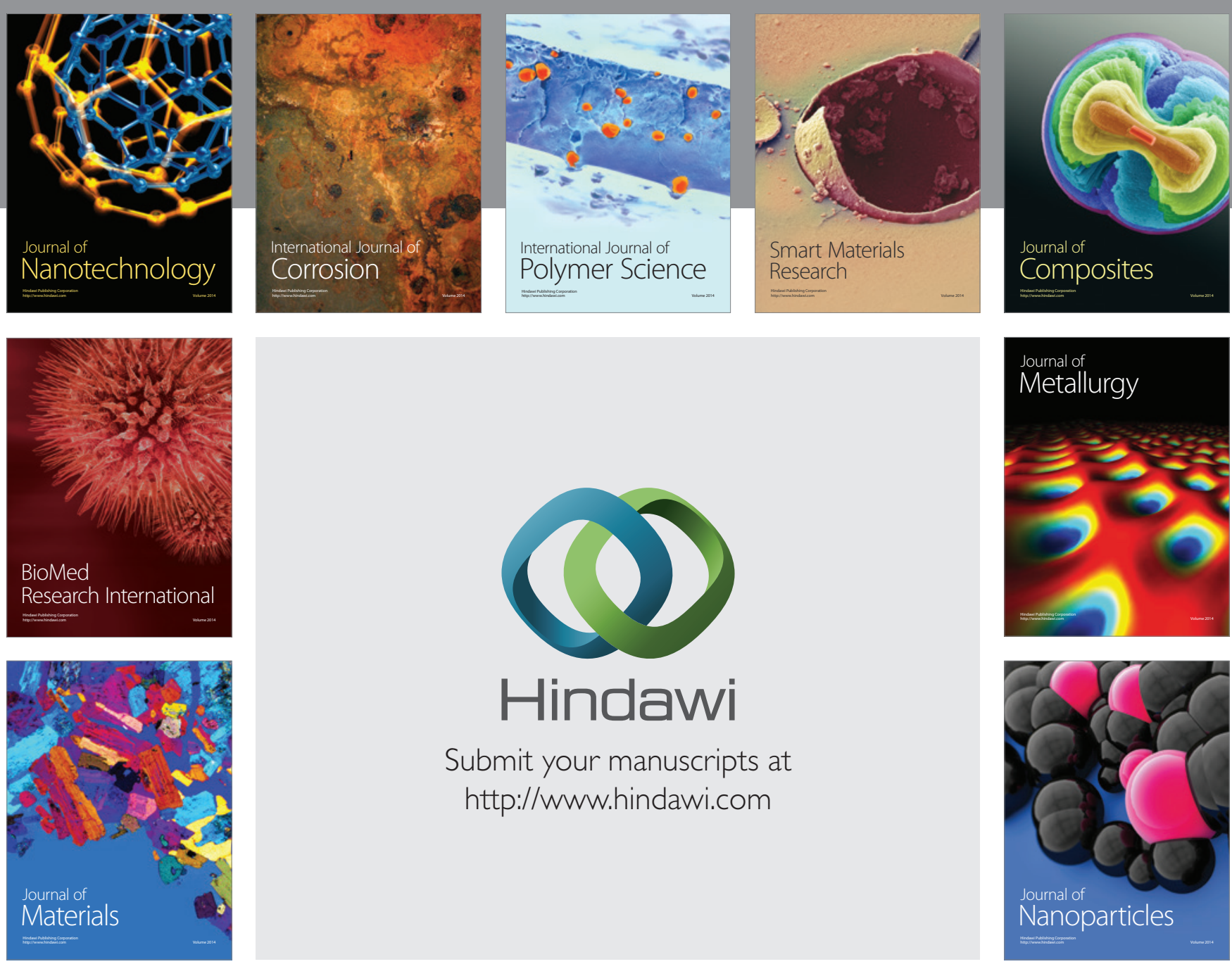

Submit your manuscripts at http://www.hindawi.com
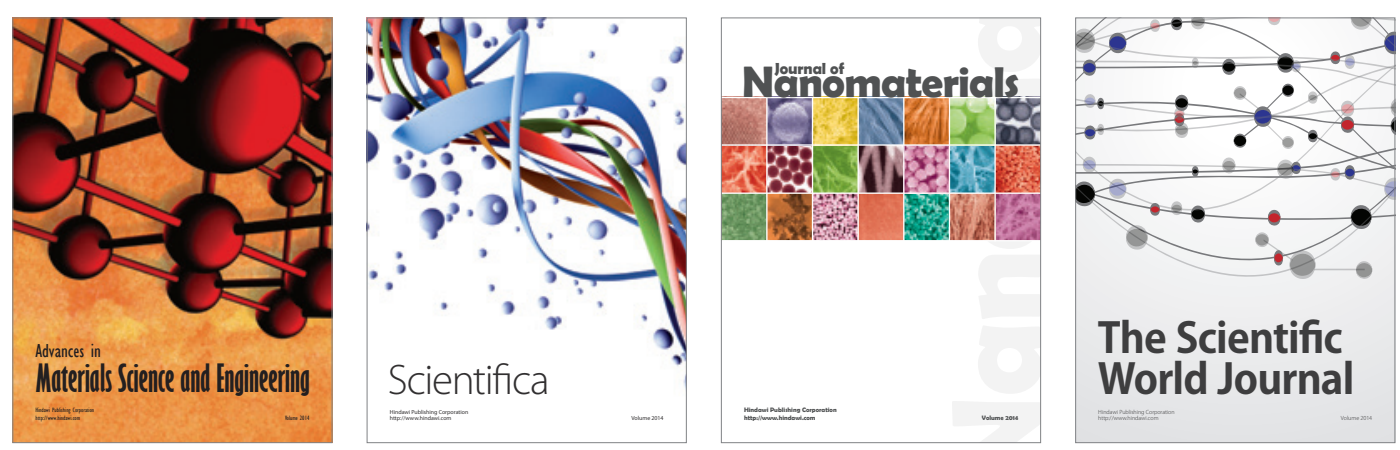

\section{The Scientific World Journal}
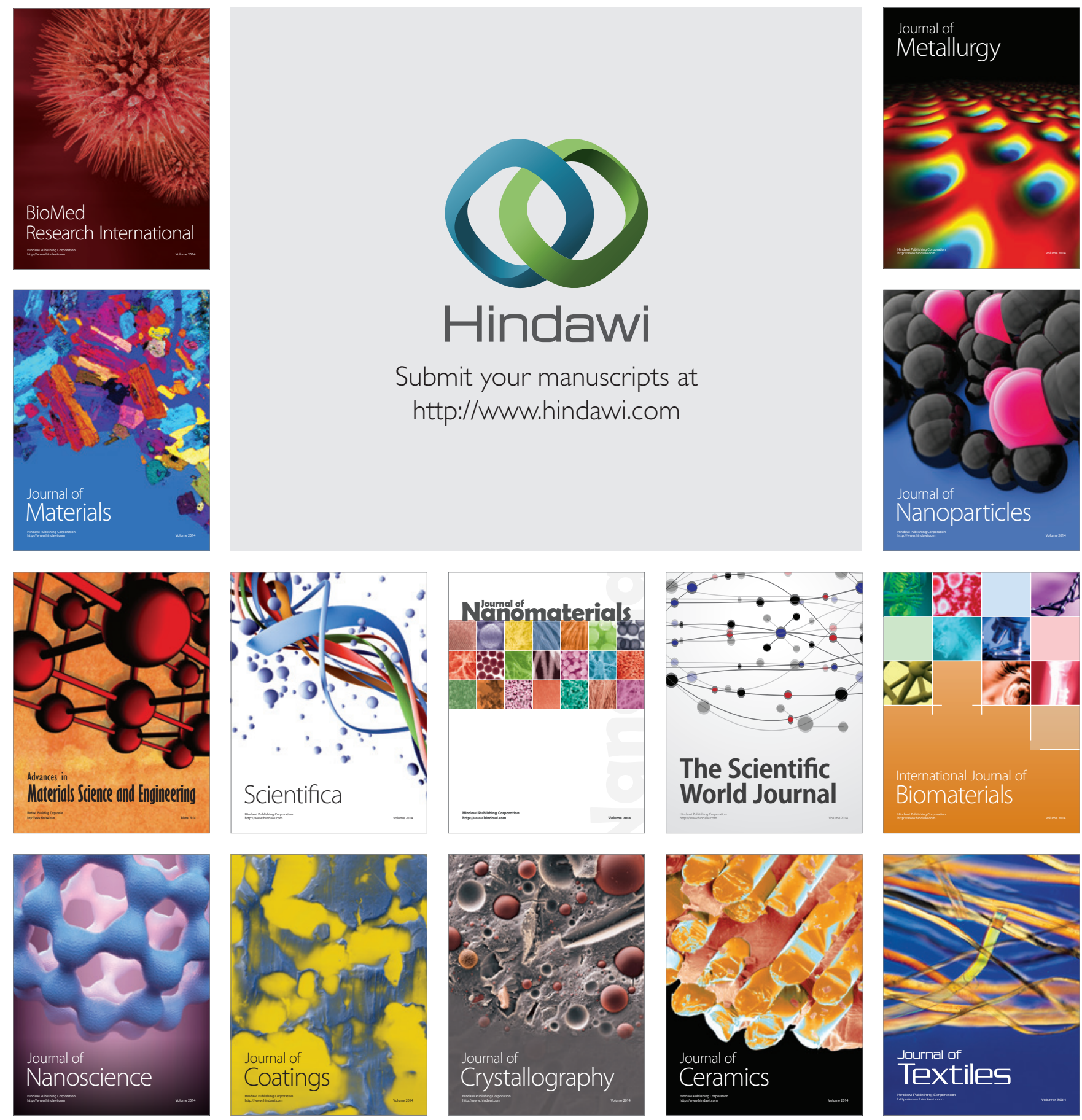